\title{
Bedeutung des Prozessreifegrads für die Patientenorientierung im Gesundheitswesen
}

\section{Importance of Process Maturity for Patient Orientation in the Health Care Sector}

Autoren

Yevgen Bogodistov ${ }^{1}$, Jürgen Moormann${ }^{1}$, Rainer Sibbel ${ }^{1}$, Oleksandr Krupskyi ${ }^{2}$, Moritz von Hanstein ${ }^{3}$, Stanyslav Grytsenko ${ }^{3}$

Institute

1 Frankfurt School of Finance \& Management, Frankfurt a. M., Deutschland

2 Dnipro National University, Dnipro, Ukraine

3 UMS Consulting GmbH \& Co. KG, Frankfurt a. M., Deutschland

\section{Schlüsselwörter}

Prozessreifegrad, Patientenorientierung, Prozessmanagement, Ukraine

Key words

Process maturity, patient orientation, process management, health care, Ukraine

\section{Bibliografie}

DOI https://doi.org/10.1055/a-0965-8373

Online-Publikation: 29.07.2019

Gesundh ökon Qual manag 2020; 25: 37-42

(c) Georg Thieme Verlag KG Stuttgart · New York ISSN 1432-2625

Korrespondenzadresse

Prof. Dr. Jürgen Moormann

Frankfurt School of Finance \& Management

Adickesallee 32-34

60322 Frankfurt a. M.

E-Mail: j.moormann@fs.de

\section{ZUSAMMENFASSUNG}

Zielsetzung Eine gute Organisation der internen Prozesse ist für ein funktionierendes Gesundheitswesen essenziell. Von besonderer Bedeutung ist der Prozess der Behandlung und Interaktion mit den Patienten, da die Wahrnehmung von Behandlung und Interaktion in einem direkten Zusammenhang mit der Patientenzufriedenheit steht. Letztere hat einen großen Einfluss auf die Gesundung der Patienten. Welche Auswirkungen der Reifegrad des Behandlungs- und Interaktionsprozesses auf die Patientenorientierung hat, wird am Beispiel einer umfangreichen Befragung von Krankenhausmanagern in der Ukraine untersucht.

Methodik Die Analyse basiert auf einer empirischen Erhebung, die bei Chefärzten und deren Stellvertretern in einer ukrainischen Großstadt, die als Modell-Stadt einer umfassenden
Gesundheitsreform fungiert, durchgeführt wurde. Anhand des Business Process Maturity Model (BPMM) haben wir unsere Hypothese, dass ein hoher Prozessreifegrad zu einem hohen Maß an Patientenorientierung führt, getestet. Dazu haben wir eine Methode zur Messung des Prozessreifegrads entwickelt und diese auf Validität und Reliabilität geprüft. An der Befragung haben 79 Chefärzte und Stellvertreter teilgenommen, die alle öffentlichen Gesundheitseinrichtungen der Stadt (Krankenhäuser, Familienärztehäuser etc.) repräsentieren.

Ergebnisse Die Untersuchung zeigt einen klaren Zusammenhang zwischen der Reife des Behandlungs- und Interaktionsprozesses und dem Grad der Patientenorientierung der jeweiligen Gesundheitseinrichtung. Die Varianz, die durch die unabhängige Variable Prozessreifegrad erklärt wird, liegt bei $16,3 \%$. Alle formativen Dimensionen zeigen einen stark signifikanten Einfluss auf das Konstrukt „Patientenorientierung”. Der Reifegrad des Behandlungs- und Interaktionsprozesses weist ebenfalls einen stark signifikanten Einfluss auf die Patientenorientierung auf.

Schlussfolgerung Für Gesundheitseinrichtungen ist es von großer Bedeutung, einen hohen Reifegrad des Behandlungsund Interaktionsprozesses zu erreichen, um damit dem Anspruch von Patientenorientierung gerecht werden zu können. Die Reife des Prozesses kann mit dem im Rahmen dieser Studie entwickelten Fragebogen getestet werden.

\section{ABSTRACT}

Aim Excellent organization of the internal processes is essential for a well-functioning health care system. Particularly, the process of treatment and interaction with the patients is important because the perception of treatment and interaction has a direct relation to the patients' satisfaction. The latter has a strong influence on the recovery of the patients. The impact of the maturity level of the treatment and interaction process on patient orientation is investigated at the example of an extensive survey of hospital managers in Ukraine.

Method The analysis is based on an empirical data collection conducted with hospital managers and their deputies in a large Ukrainian city, which is acknowledged as a 'model city' with regard to a comprehensive health care reform in the country. By means of the Business Process Maturity Model (BPMM) we have tested our hypothesis that a high level of process maturity leads to a high level of patient orientation. For this purpose, we 
In der betriebswirtschaftlichen Literatur wurde bereits angenommen, dass ein hoher Grad von Prozessreife mit hoher Kundenorientierung korreliert [20, 21]. Diese konsequente Form der Kundenorientierung wird heute als Kundenzentrierung bezeichnet [22]. Analog stellt eine ausgeprägte Patientenorientierung auch im Gesundheitswesen die moderne und angestrebte Sicht auf die Qualität der Versorgungsdienstleistungen dar [8]. Im Sinne des globalen Trends zu einer Orientierung auf das sehr umfassend verstandene „Patientenerlebnis” gewinnen die Interaktionsprozesse und ihr Reifegrad daher immer mehr an Bedeutung [23].

Die Ergebnisse unterstützen unsere Vermutung, dass eine größere Prozessreife zu einer größeren Prozessinnovation im Sinne von Verbesserung und Anpassung an Veränderungen beiträgt. Der Prozess, den wir untersucht haben, ist ein gutes Beispiel für eine Prozessinnovation (in Abgrenzung zur reinen Prozessverbesserung), weil sich mehrere Aspekte des Prozesses mit der Gesundheitsreform in der Ukraine substantiell verändert haben, die aufgrund der hohen Prozessreife aber eben nicht mit einer verringerten Patientenorientierung einhergingen.

\section{FAZIT}

In diesem Beitrag haben wir die Prozessreife in allen Krankenhäusern und sonstigen medizinischen Einrichtungen einer großen ukrainischen Stadt, die als Modell für die Gesundheitsreform dient, untersucht. Unsere Befragung umfasste nahezu die gesamte Zahl der Krankenhausmanager (Chefärzte bzw. deren Stellvertreter). Am Beispiel des Behandlungs- und Interaktionsprozesses mit den Patienten haben wir gezeigt, dass die Prozessreife kein statischer Zustand ist, sondern sich vielmehr in einem permanenten „Work in Progress" befindet. Dieses wird insbesondere in Zeiten großer Veränderungen wie der aktuellen Gesundheitsreform in der Ukraine deutlich.

Die Untersuchung zeigt einen klaren Zusammenhang zwischen der Reife des Behandlungs- und Interaktionsprozesses und der Patientenorientierung der jeweiligen Gesundheitseinrichtung. Diejenigen Krankenhäuser, die in unserer Untersuchung eine große Prozessreife aufweisen, zeigen auch hohe Werte beim Einbezug der Patienten in die Diagnose sowie bei der patientenspezifischen Anpassung der Behandlung. Damit erhöht sich die Patientenzufriedenheit, die wiederum einen positiven Einfluss auf die Genesung der Patienten hat. Dementsprechend ist es für die Gesundheitseinrichtungen von großer Bedeutung, einen hohen Reifegrad ihrer Prozesse zu erreichen.
Literatur

[1] Boerner S, Dütschke E. The impact of charismatic leadership on followers' initiative-oriented behavior. Health Care Manage Rev 2008; 33: $332-340$

[2] Gilbert S, Laschinger HKS, Leiter M. The mediating effect of burnout on the relationship between structural empowerment and organizational citizenship behaviours. J Nurs Manag 2010; 18: 339-348

[3] Hammer M, Champy J. Reengineering the corporation. New York, NY: Harper Collins, 1993

[4] Kohlbacher M. The effects of process orientation: a literature review. Business Process Management Journal 2010; 16: 135-152

[5] Dumas M, La Rosa M, Mendling J, Reijers HA. Fundamentals of Business Process Management. Berlin, Heidelberg: Springer, 2013

[6] Schmelzer HJ, Sesselmann W. Geschäftsprozessmanagement in der Praxis. 8., überarb. u. erweit. Aufl., München: Hanser, 2013

[7] Rosemann M, vom Brocke J. The Six Core Elements of Business Process Management. In: vom Brocke J, Rosemann M (Hrsg.). Handbook on Business Process Management, Bd. 1: Introduction, Methods, and Information Systems. Berlin Heidelberg: Springer, 2015: 105-122

[8] Hellmann W. Das wettbewerbsfähige Krankenhaus - Worauf es ankommt. Gesundheitsökonomie \&Qualitätsmanagement 2017; 23: 35-42

[9] Eckert H, Geyer S. Anforderungen an prozessorientierte Qualitätsmanagementsysteme im Gesundheitswesen - Eine qualitative Studie zu Umsetzungsempfehlungen. Gesundheitsökonomie \& Qualitätsmanagement 2005; 10: 102-110

[10] Hellmann W. Kundenorientierung und Qualität im Krankenhaus - ein Paradigmenwechsel ist unverzichtbar! Gesundheitsökonomie \& Qualitätsmanagement 2016; 22: 144-149

[11] Schneider J, Kaplan SH, Greenfield S, Li W, Wilson IB. Better physicianpatient relationships are associated with higher reported adherence to antiretroviral therapy in patients with HIV infection. J Gen Intern Med 2004; 19: 1096-1103

[12] Schang L, Sundmacher L, Grill E. Neue Formen der Zusammenarbeit im ambulanten und stationären Sektor: ein innovatives Förderkonzept. Das Gesundheitswesen 2019; im Internet: https://www.thieme-connect.com/products/ejournals/html/10.1055/a-0829-6465

[13] Bogodistov Y, Moormann J, Sibbel R. Beyond Health Care Reform: How Process Management Can Alter Patients' Experience. In: Academy of Management Proceedings. 2018: 12544

[14] Röglinger M, Pöppelbuß ], Becker ]. Maturity models in business process management. Business Process Management Journal 2012; 18: 328-346

[15] van Looy A. Business Process Maturity: A Comparative Study on a Sample of Business Process Maturity Models. Springer: Cham, 2014

[16] van Looy A, De Backer M, Poels G, Snoeck M. Choosing the right business process maturity model. Information \& Management 2013; 50: 466-488

[17] Hogrebe F, Nüttgens M. Business Process Maturity Model (BPMM): Konzeption, Anwendung und Nutzenpotenziale. HMD Praxis der Wirtschaftsinformatik 2009; 46: 17-25

[18] OMG. Business Process Maturity Model Specification Version 1.0. OMG 2008; im Internet: https://www.omg.org/spec//BPMM/

[19] Skaggs BC, Youndt M. Strategic positioning, human capital, and performance in service organizations: a customer interaction approach. Strat Mgmt J 2004; 25: 85-99

[20] Chen S-H, Chen H-G, Yen DC. An empirical study of software process maturity, TQM practices and organizational characteristics in Taiwanese companies. Total Qual Manage Bus Excel 2005; 16: 1091-1102

[21] Vukšić V, Štemberger M. Adoption of business process orientation practices: Slovenian and Croatian survey. Business Systems Research 2010; 1: 5-19

[22] Shah D, Rust RT, Parasuraman A, Staelin R, Day GS. The Path to Customer Centricity. Journal of Service Research 2006; 9: 113-124; im Internet: http://dx.doi.org/10.1177/1094670506294666

[23] Bleich S. How does satisfaction with the health-care system relate to patient experience? Bulletin of the World Health Organization 2009; 87: 271-278; im Internet: http://dx.doi.org/10.2471/blt.07.050401 